\title{
SYMPTOMATIC BASILAR ARTERY VASOSPASM FOLLOWING PERIMESENCEPHALIC NONANEURYSMAL SUBARACHNOID HEMORRHAGE
}

\author{
Gülçin BENBİR ŞENEL, Uğur UYGUNOĞLU, Birsen İNCE \\ İstanbul University-Cerrahpaşa, Cerrahpaşa Faculty of Medicine, \\ Department of Neurology, İstanbul, TURKEY
}

\begin{abstract}
Perimesencephalic non-aneurysmal subarachnoid hemorrhage (PNSAH) is characterized by the presence of subarachnoid hemorrhage anterior to the mesencephalon with no evidence of an intracranial aneurysm. Basilar vasospasm following PNSAH is very rarely reported, and typically does not cause clinical symptoms. Here we present a patient with clinical symptomatology due to basilar vasospasm following PNSAH. Case report: A 40-year-old male patient was admitted due to severe headache, nausea, vomiting and confusion of sudden onset. It was noted that he had similar symptoms two weeks ago, and diagnosed to have PNSAH. Patient admitted due to exacerbation of previous presenting symptomatology had a four-vessel cerebral digital-subtraction angiography, which revealed vasospasm of basilar artery, together with some regression in PNSAH. He was hospitalized and given symptomatic treatment as hydration, nonsteroidal anti-inflammatory analgesics, and anti-emetics. His symptoms resolved completely within two days, and further intervention was not planned. Control DSA after one month revealed no vasospasm or any other abnormality in basilar artery, in addition with total resorption of PNSAH. Conclusion: Perimesencephalic non-aneurysmal subarachnoid hemorrhage should be distinguished from other subarachnoid hemorrhages, as it has better prognosis and fewer complications. On the other hand, although rare and usually asymptomatic, basilar vasospasm should be kept in mind especially if clinical deterioration occurs during the course of PNSAH.
\end{abstract}

Keywords: Basilar artery, vasospasm, perimesencephalic nonaneurysmal subarachnoid hemorrhage.

Address for Correspondence: Assoc. Prof. Gülçin Benbir Şenel, MD. İstanbul University-Cerrahpaşa, Cerrahpaşa Faculty of Medicine, Department of Neurology, 34098, Fatih 34098 İstanbul, Turkey.

Phone: +902124143000 E-mail: drgulcinbenbir@yahoo.com

Received: 01.02.2019 Accepted: 20.08.2019

ORCID IDs: Gülçin Benbir Şenel 0000-0003-4585-2840, Uğur Uygunoğlu 0000-0003-2866-4004, Birsen İnce 0000-0002-6446-4897.

Please cite this article as following: Benbir Şenel G, Uygunoğlu U, İnce B. Symptomatic basilar artery vasospasm following perimesencephalic nonaneurysmal subarachnoid hemorrhage. Turkish Journal of Cerebrovascular Diseases 2021; 27(1): 56-59 doi: 10.5505/tbdhd.2020.28863 
Benbir Şenol et al.

\section{ANEVRIZMAL OLMAYAN PERIMEZENSEFALIK SUBARAKNOID KANAMAYA BAĞLI SEMPTOMATIK}

\section{BAZILER ARTER VAZOSPAZMI}

\section{ÖZ}

Perimezensefalik anevrizmal olmayan subaraknoid kanama (PNSAK) intrakraniyal bir anevrizmaya dair kanıt olmaksızın mezensefalonun ön kısmında izlenen subaraknoid kanama ile şekillenir. PNSAK sonrası baziler vazospazm oldukça nadir olarak bildirilmiștir ve tipik olarak klinik bir bulguya neden olmaz. Burada, PNSAK sonrasında gelişen baziler vazospazm nedeniyle klinik şikayetleri ortaya çıkan bir hasta sunulmaktadır. Kırk yaşında erkek hasta ani başlayan şiddetli baş ağrısı, bulantı, kusma ve şuur bulanıklığı ile başvurdu. Hastanın iki hafta önce benzer şikayetlerinin olduğu ve PNSAK tanısı aldığı öğrenildi. Eski başvuru şikayetlerinin alevlenmesi ile başvuran hastaya dört sistem dijital serebral anjiografi (DSA) çekildi ve PNSAK'da hafif regresyon ile birlikte baziler arter vazospazmı izlendi. Hastanın yatışı sağlanarak bol hidrasyon, steroitdışı anti-enflamatuar analjezikler ve anti-emetikler şeklinde semptomatik tedavi başlandı. Hastanın şikayetleri iki gün sonra tama yakın düzelmesi nedeniyle ek girişim düşünülmedi. Bir ay sonra tekrarı yapılan DSA incelemesinde baziler arterde vazospazm veya herhangi bir problem olmadığı ve PNSAK'ın tam olarak absorbe olduğu izlendi. Perimezensefalik anevrizmal olmayan subaraknoid kanamanın, daha iyi bir prognoza ve daha az komplikasyona sahip olması nedeniyle, diğer subaraknoid kanamalardan ayırt edilmesi gerekmektedir. Diğer yandan, nadir ve genellikle asemptomatik olmasına karşın, özellikle PNSAK'ın seyrinde klinik kötüleşmenin ortaya çıkması durumunda, baziler vazospazm akla getirilmelidir. Anahtar Sözcükler: Baziler arter, vazospazm, perimezensefalik anevrizmal olmayan subaraknoid kanama.

\section{INTRODUCTION}

Vasospasm following subarachnoid hemorrhage (SAH) is one of the leading causes of high morbidity and mortality. Prompt diagnosis of SAH is therefore of great importance for appropriate therapy to avoid ischemic insults (1). Cerebral vasospasm as a complication of $\mathrm{SAH}$ seems to be the result of prolonged smooth muscle contraction mediated by oxyhemoglobin, either through its direct effect on the muscle fibers or through indirect mechanisms such as the local release of vasoactive substances from the arterial wall or the production of free radicals and lipid peroxides (1-4). Although radiological cerebral vasospasm is often in SAH of aneurismal origin, vasospasm associated with clinical symptomatology is reported to be less than $30 \%$ in four-vessel cerebral digital subtraction angiography (DSA) (2-5).

Spontaneous non-aneurysmal subarachnoid hemorrhages constitute about $15 \%$ of SAH patients, and generally have a better short and long term outcome (6). Cerebral vasospasms, either detected in DSA or associated with clinical symptoms, are reported to occur very rarely following spontaneous non-aneurysmal SAH of unknown origin (7-9). There are few case reports documented to have basilar vasospasm following perimesencephalic non-aneurysmal subarachnoid hemorrhage (PNSAH) $(2,3,5,10,11)$. Here we present a patient presenting with clinical

Turkish Journal of Cerebrovascular Diseases 2021; 27(1): 56-59 symptomatology due to basilar vasospasm following perimesencephalic non-aneurysmal subarachnoid hemorrhage.

\section{CASE REPORT}

A 40-year-old male patient was admitted due to severe headache, nausea, vomiting and confusion of sudden onset. In past medical history, it was learnt that he had similar symptoms two weeks ago and had been diagnosed to have perimesencephalic subarachnoid hemorrhage in another center (Figure 1). He had had complete recovery two days after symptomatic treatment, and no cerebral angiography had been performed. Upon deterioration of his clinical table, he was admitted to our Emergency Department.

On his neurological examination, no lateralizing feature was found; there was no meningeal irritation sign, and systemic examination was also within normal limits. His past medical history was otherwise unremarkable.

He denied use of any drugs or substances. Routine biochemical tests were found within normal limits. Cranial computed tomography showed no re-bleeding or cerebral infarction; on the contrary, PNSAH was regressed to some extent. Four-vessel cerebral DSA performed, which revealed cerebral vasospasm of basilar artery (Figure 2). 


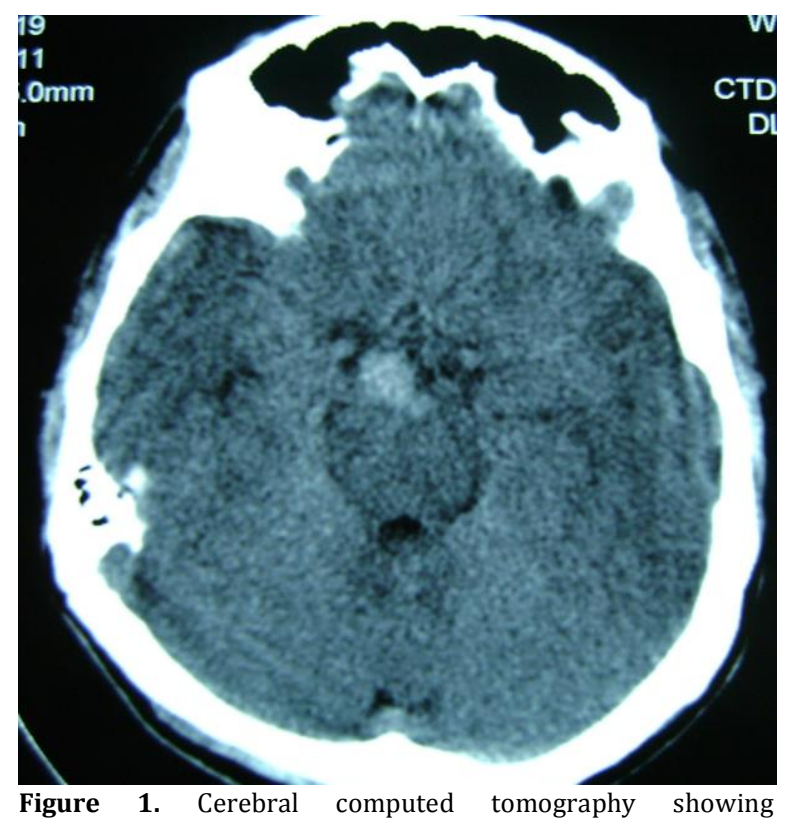
Figure 1. Cerebral computed tomography
perimesencephalic hemorrhage at first admission.

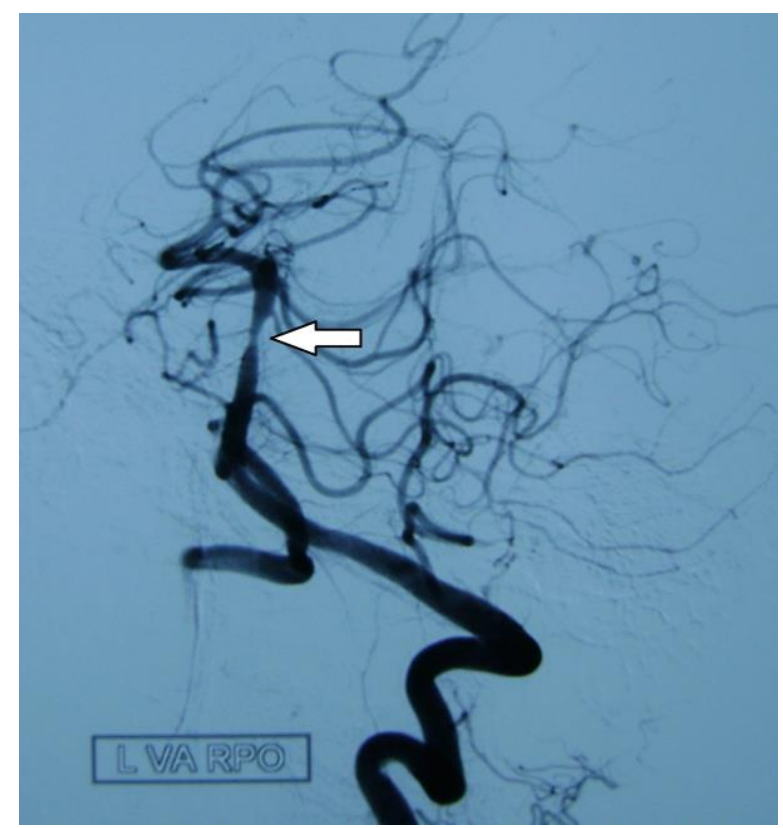

Figure 2. Cerebral vasospasm of basilar artery in cerebral angiography.

DSA excluded presence of any aneurysms or any other probable cause of perimesencephalic $\mathrm{SAH}$.

He was hospitalized and given symptomatic treatment as hydration, nonsteroidal antiinflammatory analgesics, and anti-emetics. His symptoms resolved almost completely within two days, and no further intervention was therefore planned. Repeat DSA performed one month following his admission revealed that basilar artery recovered completely and simultaneously (Figure 3), and full resorption of PNSAH was also noted. Informed consent was signed by the patient for this report.

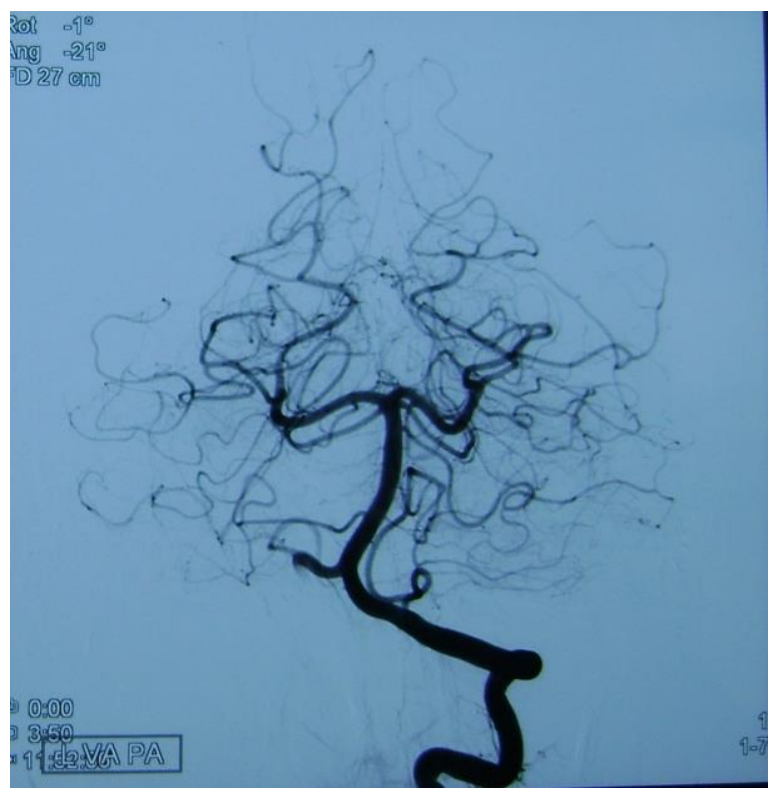

Figure 3. Control cerebral angiography showing complete resolution of basilar vasospasm.

\section{DISCUSSION AND CONCLUSION}

Perimesencephalic

non-aneurysmal subarachnoid hemorrhage is located immediately anterior to the midbrain, with or without extension of blood to the anterior part of the ambient cistern or to the basal part of the sylvian fissure (6). This type of SAH is considered to be non-arterial hemorrhage in origin due to its clinical presentation as slower onset of headache, infrequent loss of consciousness, lack of blood in brain parenchyma or ventricular system, and benign clinical course (4). The complications of PNSAH are also less frequent than aneurysmal $\mathrm{SAH}$, as is for the occurrence of cerebral vasospasm. Probably because of small amount of hemorrhage in PNSAH, cerebral vasospasm is rarely documented (10). Angiographic basilar vasospasm following PNSAH was reported as 3$20 \%$ (12), and only few patients were reported in the literature to have clinically symptomatic basilar vasospasm $(2,3,5,9,11)$.

Clinical features of vasospasm most frequently develop within 6 to 8 days after SAH

Turkish Journal of Cerebrovascular Diseases 2021; 27(1): 56-59 
(4). Symptomatology in relation to vasospasm shows variability according to the region of cerebral ischemia. It was suggested that clinical findings of basilar vasospasm following PNSAH are less prominent than that of aneurysmal SAH because arterial vasospasm affecting the posterior circulation is mild and focal $(12,13)$. Clinical deterioration associated with vasospasm is also reported to be very low in patients with SAH of unknown origin $(7,11)$. Our patient presented here was presented with severe headache, nausea, vomiting and confusion starting two weeks after the onset of PNSAH. We believe that these symptoms were related to basilar vasospasm, but not due to PNSAH; because first his symptoms started two weeks after PNSAH following clinical recovery, and secondly, neuroimaging showed that PNSAH was regressed while basilar vasospasm was angiographically detected. In control DSA of the patient performed one month after his admission to our department, basilar vasospasm was spontaneously and completely recovered, and our patient was also symptom-free.

In conclusion, perimesencephalic nonaneurysmal subarachnoid hemorrhage should be differentiated from other SAH of aneurismal origin, as it has better prognosis and fewer complications. Basilar vasospasm occurs rarely following PNSAH, and it is even rarer for basilar vasospasm to cause clinical symptoms; nevertheless, basilar vasospasm should be kept in mind in the presence of clinical deterioration during the course of PNSAH.

\section{REFERENCES}

1. Anderson GB, Ashforth R, Steinke DE, et al. CT Angiography for the detection of cerebral vasospasm in patients with acute subarachnoid hemorrhage. Am J Neuroradil 2000; 21(6): 1011-1015.

2. Alexander MSM, Dias PS, Uttley D. Spontaneous subarachnoid hemorrhage and negative cerebral panagiography. J Neurosurg 1986; 64(4): 537-542.
3. Barlow P. Incidence of delayed cerebral ischaemia following subarachnoid hemorrhage of unknown cause. J Neurol Neurosurg Psychiatry 1985; 48(2): 132-136.

4. Schwartz TH, Solomon RA. Perimesencephalic nonaneurysmal subarachnoid hemorrhage: review of the literature. Neurosurgery 1996; 39(3): 433-440.

5. Beguelin C, Seiler R. Subarachnoid hemorrhage with normal cerbral panangiography. Neurosurgery 1983; 13(4): 409-411.

6. Rinkel GJE, Wijdicks EFM, Vermeulen $M$, et al Nonaneurysmal perimesencephalic subarachnoid hemorrhage: CT and MR patterns that differ from aneursym rupture. Am J Neuroradiol 1991; 12(5): 829-834.

7. Lang EW, Khodair A, Barth $\mathrm{H}$, et al. Subarachnoid hemorrhage of unknown origin and the basilar artery configuration. J Clin Neurosci 2003; 10(1): 74-78.

8. Gross BA, Lin N, Frerichs KU, et al. Vasospasm after spontaneous angiographically negative subarachnoid hemorrhage. Acta Neurochir (Wien) 2012; 154(7): 11271133.

9. Alturki AY, Alamri AS, Badawy MM, Lo BW. Basilar artery vasospasm after pretuncal non-aneurysmal subarachnoid hemorrhage responding to milrinone. Neurosciences (Riyadh) 2017; 22(2): 134-137.

10. Hsu W, Pradilla G, Garonzik IM, et al. Pretruncal nonaneurysmal subarachnoid hemorrhage causing basilar artery vasospasm. Neurocrit Care 2010; 13(2): 256-260.

11. Mayor S, Erro ME, Zazpe I, et al. Pontine stroke due to vasospasm secondary to perimesencephalic subarachnoid hemorrhage. Neurologia 2008; 23(4): 256-258.

12. Kassell NF, Sasaki T, Colohan AR, et al. Cerebral vasospasm following aneurismal subarachnoid hemorrhage. Stroke 1985; 16(4): 562-572.

13. Canhao P, Pinto AN, Pinhoe MT, et al. Hemorrhagia perimesencephalica. Acta Med Port 1992; 5: 473-475.

\section{Ethics}

Informed Consent: The authors declared that informed consent form was signed by the patient.

Copyright Transfer Form: Copyright Transfer Form was signed by the authors.

Peer-review: Internally peer-reviewed.

Authorship Contributions: Surgical and Medical Practices: GBŞ, UU, Bİ, Concept: GBŞ, UU, Bİ, Design: GBŞ, UU, Bİ, Data Collection or Processing: GBŞ, UU, BI, Analysis or Interpretation: GBŞ, UU, Bİ, Literature Search: GBŞ, UU, Bİ, Writing: GBŞ, UU, Bİ.

Conflict of Interest: No conflict of interest was declared by the authors.

Financial Disclosure: The authors declared that this study received no financial support. 